\title{
Performance of Maize Hybrids (Zea mays L.) under Different Sowing Windows
}

\author{
S.V. Shingne ${ }^{1}$, B.V. Asewar ${ }^{2}$ and Y.E. Kadam 3* $^{*}$ \\ ${ }^{1}$ Department of Agriculture Meteorology, ${ }^{2}$ Dry land Agriculture Research Center, \\ ${ }^{3}$ Department of Agriculture Meteorology, VNMKV, Parbhani, Maharashtra, India \\ *Corresponding author:
}

\section{Keywords}

Maize, Hybrids, Sowing dates and Yield

Article Info

Accepted:

15 May 2019

Available Online:

10 June 2019

\section{A B S T R A C T}

The field experiment was conducted at Research farm of Department of Agricultural Meteorology, college of Agriculture, Parbhani during kharif 2017 to study the performance of maize hybrids (Zea mays L.) under different sowing windows. The experiment comprised of five dates i.e. $25^{\text {th }} \mathrm{SMW}, 26^{\text {th }} \mathrm{SMW}, 27^{\text {th }} \mathrm{SMW}, 28^{\text {th }} \mathrm{SMW}$ and $29^{\text {th }} \mathrm{SMW}$ as main plot treatment with two maize hybrid viz. $\mathrm{H}_{1}$ (PIONEER-3501) and $\mathrm{H}_{2}$ (MONSANTO-9126) as sub plot treatments and replicated thrice. Factorial Randomized Block Design, gross and net plot sizes were $6.0 \times 5.0 \mathrm{~m}^{2}$ and $4.8 \times 4.2 \mathrm{~m}^{2}$, respectively with spacing of $60 \times 30 \mathrm{~cm}$. The results revealed that among the five different dates of sowing. $\mathrm{D}_{1}-25^{\text {th }}$ SMW sowing and hybrid $\mathrm{H}_{1}$ (PIONEER-3501) resulted in crop sown with higher growth and yield parameters significantly i.e. Plant height, functional leaves, days to $50 \%$ tasseling, days to $50 \%$ silking, Number of cob per plant, length of cob, diameter of cob, Number of grain per cob and test weight also first date of sowing $\mathrm{D}_{1}-25^{\text {th }}$ SMW significantly highest grain yield $(4969 \mathrm{~kg} / \mathrm{ha})$ followed by $\mathrm{D}_{2}(4816 \mathrm{~kg} / \mathrm{ha}), \mathrm{D}_{3}(4627$ $\mathrm{kg} / \mathrm{ha}) \mathrm{D}_{4}\left(4424 \mathrm{~kg} / \mathrm{ha}\right.$ ) and $\mathrm{D}_{5}(4131 \mathrm{~kg} / \mathrm{ha})$ and among hybrid $\mathrm{H}_{1}$ (PIONEER-3501) (4609 $\mathrm{kg} / \mathrm{ha}$ ) and $\mathrm{H}_{2}$ (MONSANTO-9126) (4578 kg/ha) respectively.

\section{Introduction}

Maize is called as queen of cereal due to its great importance in human, animal diet and high yielding ability. It efficiently utilizes solar energy and has immense potential for higher yield, and called as "Miracle Crop". It is the crop of the future as mentioned by the Father of Green Revolution, Renounced Nobel Laureate Dr. Norman E. Borlaug. Maize plays a vital role in ensuring food security as well as nutritional security through quality protein (Rawool, 2004). In India, area and production of maize are about 9.23 million hectares and 23.73 million tonnes respectively, having average productivity about $2564 \mathrm{~kg} \mathrm{ha}^{-1}$. In Maharashtra, the area and production of maize is about 1.05 million hectares and 2.20 million tonnes production with the productivity of $2080 \mathrm{~kg} \mathrm{ha}^{-1}$ (Anonymous, 2015). It ranked next to rice, wheat and sorghum in respect of area and production. Though it is consumed all over the country but it is a staple food of people in 
hilly and sub mountain area of North India. It is extensively grown in Uttar Pradesh, Bihar, Rajasthan, Madhya Pradesh etc. (Dayanand and Jain, 1994). The productivity of maize in Marathwada is low (1983 $\left.\mathrm{kg} \mathrm{ha}^{-1}\right)$ as compared to Maharashtra i.e. $2066 \mathrm{~kg} \mathrm{ha}^{-1}$.

Climate variability has a direct influence on the quantity and quality of maize production as water shortage combined with thermal stress adversely effect maize productivity. To deal with the impact of climate change, the potential adaption strategies are changing sowing dates; crop diversification, integrated farming system, etc. Optimum sowing date is important to mitigate climate change. Growing a suitable hybrid at an optimum sowing time may be better agronomic option under the water starved condition. There is need to evaluate the different maturity hybrids of maize for their growth and yield under varying sowing dates (Pathak et al., 2011).

\section{Materials and Methods}

The field experiment was conducted during the Kharif 2017 at Research farm of Department of Agricultural Meteorology, college of Agriculture Parbhani to study the performance of maize hybrids (Zea mays L.) under different sowing windows. The experiment was laid out in Factorial Randomized Block Design replicated three times. The treatments comprised of five dates of sowing i.e., $25^{\text {th }}$ SMW, 26 ${ }^{\text {th }}$ SMW, 27 $7^{\text {th }}$ SMW, $28^{\text {th }}$ SMW and $29^{\text {th }}$ SMW in main plots and two maize hybrid $\mathrm{H}_{1}$ (PIONEER3501) and $\mathrm{H}_{2}$ (MONSANTO-9126) in sub plots. Gross and net plot sizes were $6.0 \times 5.0$ $\mathrm{m}^{2}$ and $4.8 \times 4.2 \mathrm{~m}^{2}$, respectively. Sowing was done by dibbling method with spacing of $60 \times 30 \mathrm{~cm}$. The entire recommended packages of practices were adopted. The crop was harvested at physiological maturity. Data on growth, yield components and yields were recorded as per procedure. The observations pertaining to all biometric observation 15 days interval and post-harvest yield attributes observations were recorded at harvest.

\section{Results and Discussion}

\section{Growth parameters}

Perusal of data presented in Table 1 revealed that significant differences were observed done to dates of sowing and hybrids in respect of growth characters. Date of sowing significantly influenced plant height and functional leaves. Mean plant height was significantly higher in sowing date i.e. $\mathrm{D}_{1}$ (SMW 25) which was superior over $\mathrm{D}_{4}(28$ SMW) and $\mathrm{D}_{5}$ (29 SMW) and was found at par with $\mathrm{D}_{2}$ (26 SMW) and $\mathrm{D}_{3}$ (27 SMW) sowing dates. These results are similar by Idikut et al., (2005), Namakka et al., (2008). However the hybrid $\mathrm{H}_{1}$ (PIONEER 3501) recorded highest plant height and functional leaves which followed by hybrid $\mathrm{H}_{2}$ (MONSANTO 9126) and interaction between date of sowing and hybrid was nonsignificant. Decrease in plant height and functional leaves in late sowing were due to shorter growing period. These results are similar to those of by Shah et al., (2012) and Jadhav et al., (2015).

\section{Days to $\mathbf{5 0 \%}$ tasseling and days to $\mathbf{5 0 \%}$ silking}

The data on mean number of days required for $50 \%$ tasseling and $50 \%$ silking plant as influenced by different treatments are presented in Table 1. Mean number of days required to $50 \%$ tasseling and $50 \%$ silking was significantly higher in treatment $\mathrm{D}_{1}$ (SMW 25) (49.5) and (53.0) respectively which was superior over the rest of sowing dates. However hybrid $\mathrm{H}_{1}$ (PIONEER 3501) (47.0) and (50.0) as per to $\mathrm{H}_{2}$ (MONSANTO 9126). This might be due to favorable weather condition with the respective treatment. 
Table.1 Periodical mean growth and yield attributing characters of maize as influenced by different treatments

\begin{tabular}{|c|c|c|c|c|c|c|c|}
\hline \multirow[t]{2}{*}{ Treatments } & \multicolumn{7}{|c|}{ Growth and yield characters } \\
\hline & $\begin{array}{c}\text { Plant } \\
\text { Height } \\
\text { (cm) }\end{array}$ & $\begin{array}{c}\text { Function } \\
\text { al } \\
\text { Leaves }\end{array}$ & $\begin{array}{l}\text { Days to } 50 \% \\
\text { tasseling }\end{array}$ & $\begin{array}{l}\text { Days to } 50 \% \\
\text { silking }\end{array}$ & $\begin{array}{l}\text { Number of } \\
\text { cob plant }^{-1}\end{array}$ & $\begin{array}{l}\text { Length of } \\
\text { cob }(\mathrm{cm})\end{array}$ & $\begin{array}{c}\text { Diameter of } \\
\text { cob }(\mathbf{c m})\end{array}$ \\
\hline \multicolumn{8}{|c|}{ Date of Sowing } \\
\hline$D_{1}\left(25^{\text {th }}\right.$ SMW $)$ & 204.08 & 14.51 & 49.50 & 53.00 & 1.53 & 16.22 & 4.85 \\
\hline$D_{2}\left(26^{\text {th }}\right.$ SMW $)$ & 200.63 & 13.85 & 47.50 & 50.50 & 1.39 & 15.28 & 4.66 \\
\hline$D_{4}\left(28^{\text {th }}\right.$ SMW $)$ & 194.75 & 13.56 & 45.50 & 47.50 & 1.26 & 13.73 & 3.99 \\
\hline$D_{5}\left(29^{\text {th }}\right.$ SMW $)$ & 189.67 & 13.71 & 44.50 & 46.50 & 1.11 & 13.02 & 3.44 \\
\hline S.E. \pm & 2.18 & 0.16 & 1.01 & 0.71 & 0.02 & 0.13 & 0.15 \\
\hline $\mathrm{H}_{2}($ MONSANTO 9126) & 192.09 & 13.84 & 46.40 & 48.80 & 1.26 & 14.67 & 3.97 \\
\hline S.E \pm & 1.38 & 0.13 & 0.64 & 0.45 & 0.01 & 0.01 & 0.09 \\
\hline CD at $5 \%$ & 4.10 & 0.38 & 1.90 & 1.34 & 0.03 & 0.04 & 0.28 \\
\hline \multicolumn{8}{|c|}{ Interaction (D x V) } \\
\hline $\mathbf{S . E} \pm$ & 3.09 & 0.51 & 1.43 & 1.01 & 0.28 & 0.33 & 2.14 \\
\hline CD at $5 \%$ & NS & NS & NS & NS & NS & NS & NS \\
\hline General Mean & 197.81 & 13.85 & 46.70 & 49.40 & 1.29 & 14.70 & 4.13 \\
\hline
\end{tabular}


Table.2 Yield attributes of maize as influenced by different treatments

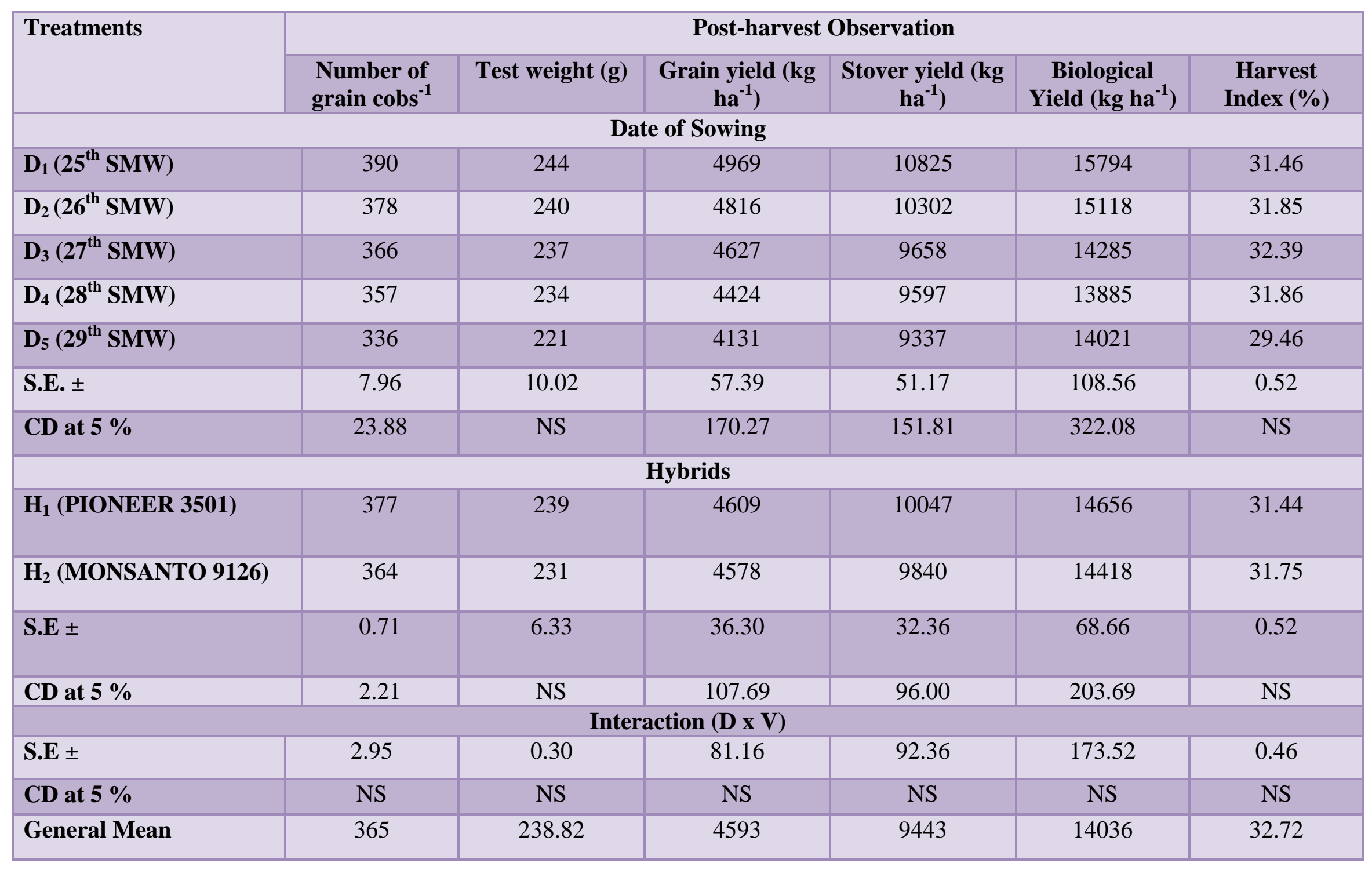


Similar results were reported by Parashar (2001) and Hemilatha et al., (2013).

\section{Yield attributes characters}

The data on mean number of cobs per plant, length of cob, diameter of cob, number of grain per cob and test weight as influenced by different sowing dates and hybrids are given in Table 1 and 2. The number of cobs per plant, length of cob, diameter of cob, number of grain per cob and test weight was considered as the most important yield contributing characters and they are varied significantly under different date of sowing and hybrids. Sowing of maize at $25^{\text {th }} \mathrm{SMW}$, significantly influenced the yield attributing characters and significantly superior over the delayed sowing. Analysis revealed that sowing done in $25^{\text {th }}$ SMW and first hybrid (PIONEER 3501) was a significantly superior followed by $26^{\text {th }} \mathrm{SMW}, 27^{\text {th }} \mathrm{SMW}, 28^{\text {th }} \mathrm{SMW}$ and $29^{\text {th }}$ SMW respectively. This might be due to favorable rainfall, temperature requirement as per crop need may have boosted crop growth in the form of higher photosynthetic accumulation and resulting higher yield parameters in early sown crop. These results are also in conformity to that of by Prodhan (2001), Rahman et al., (2001) and Namakka et al., (2008).

\section{Yields}

The data on mean grain, straw and biological yield of maize as influenced by different sowing dates and hybrids are given in Table 2 the data indicated that mean grain, straw and biological yield was $4593 \mathrm{~kg} \mathrm{ha}^{-1,} 9443 \mathrm{~kg}$ $\mathrm{ha}^{-1}$ and $14036 \mathrm{~kg} \mathrm{ha}^{-1}$ respectively. Different date of sowing significantly influenced the grains and straw yields (Table 2). The maize sown in $25^{\text {th }}$ SMW produced significantly higher grain yield (4969 kg/ha) and followed by $\mathrm{D}_{2}(4816 \mathrm{~kg} / \mathrm{ha}), \mathrm{D}_{3}$ (4627 kg/ha), $\mathrm{D}_{4}$ (4424 kg/ha) and $D_{5}(4131 \mathrm{~kg} / \mathrm{ha})$.There was
$7 \%, 11 \%$ and $17 \%$ reduction in the grain yield in $27^{\text {th }} \mathrm{SMW}, 28^{\text {th }} \mathrm{SMW}$ and $29^{\text {th }} \mathrm{SMW}$. This might be due to delayed sowing as compared to first date of sowing i.e. $25^{\text {th }}$ SMW. However among hybrid $\mathrm{H}_{1}$ (PIONEER 3501) was $\left(4609 \mathrm{~kg} / \mathrm{ha}\right.$ ) and $\mathrm{H}_{2}$ (MONSANTO 9126) $(4578 \mathrm{~kg} / \mathrm{ha})$ respectively. These results were in conformity by Pradhan (2001), Rahman et al., (2001) and Sulochana et al., (2015). The straw and biological yield was produced significantly higher in $25^{\text {th }} \mathrm{SMW}$ as compare to rest of sowing dates and first hybrid (PIONEER 3501) was more yield as compare to $\mathrm{H}_{2}$ (MONSANTO 9126) respectively.

Sowing of maize during different sowing dates significantly influenced growth and yield characters. Plant height, functional leaves, days to $50 \%$ tasseling, days to $50 \%$ silking, Number of cob per plant, length of cob, diameter of cob, Number of grain per cob and test weight were significantly more when maize sown during $25^{\text {th }}$ SMW and variety (PIONEER 3501) was sown during $25^{\text {th }}$ SMW favoured most of the growth and yield contributing characters. However $\mathrm{D}_{1^{-}}$ $25^{\text {th }}$ SMW significantly highest grain yield (4969 kg/ha) followed by $\mathrm{D}_{2}(4816 \mathrm{~kg} / \mathrm{ha}), \mathrm{D}_{3}$ (4627 kg/ha) $\mathrm{D}_{4}(4424 \mathrm{~kg} / \mathrm{ha})$ and $\mathrm{D}_{5}(4131$ $\mathrm{kg} / \mathrm{ha}$ ) and among hybrid $\mathrm{H}_{1}$ (PIONEER3501) (4609 kg/ha) and $\mathrm{H}_{2}$ (MONSANTO9126) $(4578 \mathrm{~kg} / \mathrm{ha})$.

\section{References}

Anonymous, 2015b. The current status published on website - http: //www.indiastat.in.

Dayanand and Jain, O. P. 1994. Rabi maize cultivation for enhanced production. India Fm., 43 (10): 11-12.

Hemalatha, S., Sreelatha D., Anuradha, M. and Saikumar, R. 2013. Crop weather relations in maize. J. Agrometeorlogy, Andhra Pradesh, 15(92): 165-166. 
Idikut, L., Cesur, C. and Tosun, S. 2005. Effect of planting dates and growing techniques on green yield and some characters of sweet corn. KSU Journal of Science and Engineering, 8(1): 91100.

Jadhav, A., Kumar A., Singh, A. K., Singh, I. and Das, T. K. 2015. Response of maize hybrids (Zea mays L.) to staggered sowing. Indian Journal of Agronomy, 60(3): 476-478.

Namakka, A., Abubakar, I. U., Sadik, I. A., Sharifai, A. I. and Hassas, A. H. 2008. Effect of sowing date and nitrogen level on yield and yield components of two extra early maize varieties (Zea mays L.) in Sudan savanna of Nigeria. Arpn. J., 3(2): 1-5.

Parashar, A. 2011. Phenology and productivity of maize cultivars as influenced by crop weather environment. M.Sc. Thesis, Maharana Pratap University of Agriculture and Technology, Udaipur.

Prodhan, M.S. 2001. Indian J. Agric. Sci., 71:
$55-56$.

Rahman, M. A., Magboul, E. L. and Abdelatief, E. N. 2001. Effects of sowing date and cultivar on the yield and yield components of maize in northern Sudan, paper presented at the Seventh Eastern and Southern Africa Regional Maize Conference.

Rawool, H. V. 2004. Effect of integrated nutrient management on yield and nutrient balance in maize (Zea mays L.). Indian J. Agril. Sci., 46(4): 698-701.

Shah, A., Akmal, M., Asim, M., Farhatullah, Raziuddin, and Rafi, A. 2012. Maize growth and yield in Peshawar under changing climate. Pakistan Journal of Botany, 44(6): 1, 933-938.

Sulochana, Solanki, N. S., Dhewa, J. S. and Bajia, R. 2015. Effect of sowing dates on growth, phenology and agro meterological indices for maize varieties. An International Quarterly Journal of Life Sciences. 10(3): 13391343.

\section{How to cite this article:}

Shingne, S.V., B.V. Asewar and Kadam, Y.E. 2019. Performance of Maize Hybrids (Zea mays L.) under Different Sowing Windows. Int.J.Curr.Microbiol.App.Sci. 8(06): 1982-1987. doi: https://doi.org/10.20546/ijcmas.2019.806.236 